\title{
Petrography and Geochemistry of Padhar Mafic-Ultramafic Suite Rocks, Betul Belt, Central Indian Tectonic Zone, India: Plausible Arc type Magmatism
}

\author{
Satinder Dhillon ${ }^{1 \#}$, V.Balaram ${ }^{2}$, Naval Kishore ${ }^{1}$ and Gurmeet Kaur ${ }^{1}$ \\ ${ }^{I}$ CAS in Geology, Panjab University, Chandigarh-160014, India \\ ${ }^{2}$ National Geophysical Research Institute, CSIR, Uppal road, Hyderabad-500606, India \\ Email:shellydhillon7@gmail.com
}

\begin{abstract}
Padhar Mafic-Ultramafic (PMUM) suite of rocks comprises olivine pyroxenites, pyroxenites, gabbros and diorites. Olivine pyroxenites and pyroxenites forming the ultramafic component are mainly composed of olivine, clinopyroxenes, orthopyroxenes, as cumulus phase and phlogopite as intercummulus phase with ilmenite and magnetite as accessory minerals. Gabbros and diorites comprising the mafic component of suite are mainly composed of relict pyroxenes, amphiboles, plagioclases. Geochemically, on the TAS diagram the studied samples fall in tholeiitic field. The chondrite normalized REE patterns show slight LREE enrichment and flat HREE pattern with no significant negative Eu anomalies implying insignificant or no plagioclase fractionation except in diorites. The trace element spidergrams normalised on primitive mantle show high negative $\mathrm{Nb}$ anomalies along with negative $\mathrm{Zr}$-Hf troughs in contrast to Th and Ce indicating typical subduction settings. The major oxide and trace element distributions along with Rare earth element ratios indicate that Padhar Mafic-Ultramafic suite of rocks represent the mafic magmatism in subduction environment.
\end{abstract}

Keywords: Padhar, Betul Belt, Mafic-Ultramafic, Geochemistry, Subduction.

\section{Introduction}

The peninsular India is an amalgamation of several Archean cratons by Proterozoic volcanosedimentary mobile belts (Fig. 1, inset map). One such mobile belt, i.e. the ENE-WSW trending Central Indian Tectonic Zone (CITZ) divides the Indian subcontinent into two tectono-magmatic provinces i.e., the Northern Crustal Province (NCP) comprising Bundelkand and Aravalli cratons in the north and Southern Crustal Province (SCP) comprising Bastar, Singhbhum and Dharwar cratons in the south [1].

The CITZ lies between Son-Narmada North Fault (SNNF) in north and Central Indian Shear (CIS) in the south (Fig 1) [2, 3, 4]. Three major Proterozoic supracrustal belts, Mahakoshal, Betul and Sausar occur from north to south in the CITZ. The Mahakoshal belt representing the back arc/continental rift exposes a greenstonetype volcano-sedimentary association fringed by high grade anorthositic rocks (Makrohar granulites) near the southern margin [4]. The Betul and Sausar belts are located in the west-central and southern part of the CITZ, representing active continental margin and suture zone, respectively. The Betul belt records mafic-ultramafic magmatism, extensive bimodal volcanism and contains pelites-psammopelites-calcareous metasediments, whereas the Sausar belt is conspicuous by its manganiferous metasediments and the absence of any volcanism. The Central Indian Shear (CIS) with ENE-WSW trend marks the southern boundary of CITZ and the Sausar belt [3]. The different components of the CITZ record a geological history from ca. 2.7 to ca. 0.9 Ga [4, 5]. Major regional scale faults and ductile shear zones delineating the CITZ are indications of significant crustal scale tectonism. These tectonic activities resulted in rifting, volcanism, polyphase deformation, metamorphism, and magmatism in the CITZ during the suturing of the northern and southern cratonic assemblies [1, 4].

The integrated field, petrographic, geochemical data on magmatic rocks can be used as good geodynamic indicators $[4,6,7,8]$. The trace and REE data are now extensively used to evaluate the various processes of magma generation and their source characteristics $[9,10]$. A large number of researchers have contributed to our understanding of the Mahakoshal and Sausar Mobile Belts whereas the Betul belt is geologically far less known except for descriptions of various lithological units, sulfide mineralization and some basic petrological works. Systematic scanning of the literature relevant to CITZ revealed that there is a big void of petrological-geochemical database on the magmatic rocks that form a substantial portion of this belt although these are fundamental to the understanding of the spatial and sequential tectono-magmatic evolution of this mobile belt. 


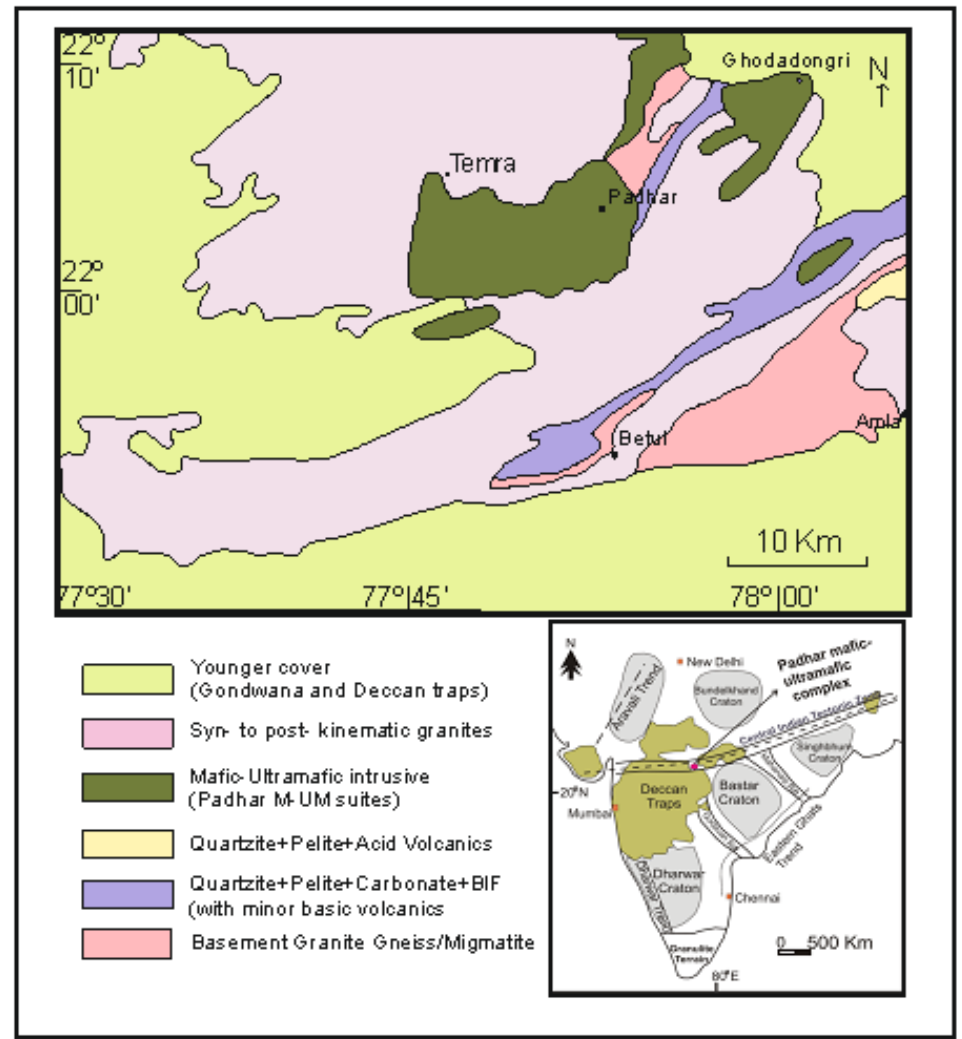

Fig 1. Generalized geological map of Betul area (modified after Roy et al, 2004). Inset map of India showing outline of Central Indian Tectonic Zone (CITZ).

\section{Geological Setting Of Betul Mobile Belt}

The narrow E-W trending Betul belt extends for about $135 \mathrm{~km}$ and is surrounded by younger Deccan traps in the east, west and south and Gondwana sediments in the north [11]. Three distinct lithologic packages with particular spatial disposition characterize the Betul belt. Psammopelitic and carbonate-BIF metasediments and bimodal mafic and felsic volcanics are conspicuous in the central and eastern part of the belt, respectively. Mafic-ultramafic rocks comprising sheets and plutons of Olivine pyroxenites, pyroxenites, hornblendepyroxenites, gabbro and diorite are mostly located in the northwestern part of the Betul belt. The belt also contains some older granite gneiss/migmatites, syn- to post-kinematic granitic rocks, pegmatites and quartz veins $[11,12,13,14]$. The rocks of Betul belt have undergone polyphase deformation. In all, three phases of progressive deformation have been recorded. The structural features of the area are mainly represented by bedding, foliation, folds and shear zones. The foliation is well developed in granite gneiss and is crudely developed in porphyroblastic gneisses. In the northern part, the regional foliation trends roughly ENE-WSW with moderate to steep southeasterly dips, while in the eastern part it is NNE-SSW with a subvertical disposition. A number of ENE-WSW striking ductile shear zones controlled the profuse granitic magmatism all along the belt $[4,15]$. The supracrustal rocks exhibit metamorphic grade varying from lower- to middle amphibolite facies [4].

The Betul belt is characterized by volcanic hosted massive sulphide deposits (VMS) of $\mathrm{Zn}$-Cu type and $\mathrm{Zn}-\mathrm{Pb}-\mathrm{Cu}$ type, hosted by the felsic volcanic rocks of bimodal volcanics. Exploration has been carried out in various areas like Bhanwra-Tekra, Bargaon-Tarora, Kehalpur, Chopna-Munrai, Banskhapa-Pipariya, Ghisi, Muariya, Koparpani, Dehalwara and Bhuyari. Most of the areas have strata bound, moderately to steeply dipping, multiple, sub-parallel lenses composed of disseminated and semi-massive ores comprising sphalerite, pyrite, galena, chalcopyrite and pyrhhotite [16].

The extensive mafic magmatism that form a substantial proportion of the Betul belt needs to be evaluated in terms petrological and geochemical parameters to comprehend the spatial and sequential tectonomagmatic evolution of this mobile belt. Little or no information is available regarding magmatic evolution of this terrain. This paper presents the petrological and geochemical investigations of the mafic-ultramafic complex of Betul belt and an attempt has been made for better understanding of the petrogenesis and tectonic setting of the complex which also contributes in deciphering the crustal evolution of Central Indian Tectonic Zone. 


\section{Petrography}

The rocks in the Padhar MUM complex are represented by Olivine Pyroxenite, Pyroxenite, Gabbros and Diorites intruded at places with mafic dykes referred here as Betul dykes. The mafic rocks are occurring in the northern and southern part while central part has ultramafic intrusions. The pyroxenites are occurring as massive outcrops in the central part of study area (Fig 2a). Gabbros are occurring in the northern part of area, of which one of the outcrops near Padhar hill stands out in topography (Fig $2 b$ ). Phenocrysts of mafic minerals are quite prominent in coarser grained outcrops of pyroxenites (Fig 2c). Cumulus to intercummulus textures are visible with naked eye in the field (Fig 2d).

Megascopiocally, Olivine Pyroxenite is a dark grey to black colored, fine to medium grained rock. Under the microscope it shows equigranular, panidiomorphic texture mainly comprising euhedral to subhedral olivines, euhedral pyroxenes forming the primary magmatic cummulus phase and phlogopite occurring as intercummulus phase and minor opaques like titanomagnetite, ilmenite as accessory phases (Fig 3a). In thin sections of olivine pyroxenites, at places olivine grains are found enclosed inside orthopyroxene grain which in turn is surrounded by clinopyroxene (Fig 3b). Olivine grains are cracked and show reaction rims.
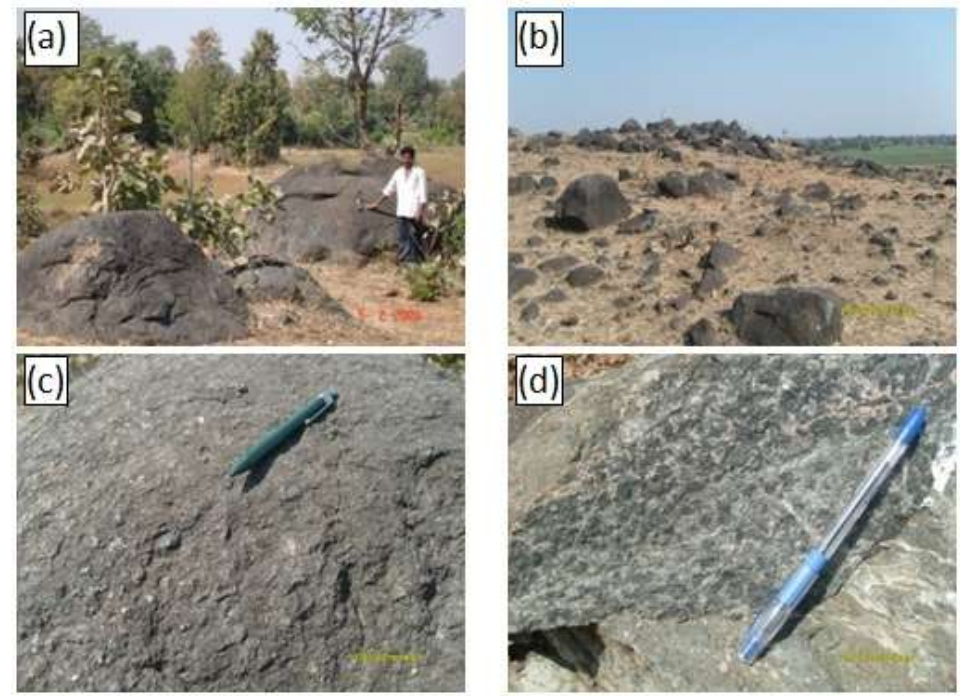

Fig 2. Field photographs depicting the outcrop exposures and megascopic textures of mafic and ultramafic rock varieties in PMUM complex (a) Gabbro outcrop; (b) Outcrop of ultramafic variety on Padhar Hill in Padhar Village. (c) Medium to coarse grained pyroxenite variety with prominent phenocryst of mafic minerals; (d) Pyroxenite variety with cumulates of mafic minerals.

Pyroxenite, the most predominant variety of ultramafic rock in the area is dark green to greenish grey in color and fine to medium grained rock. Microscopically, the rock shows primary cumulus texture where clinopyroxenes with two directional cleavages form the cumulus phase. The pyroxenes are partially altered to amphiboles and actinolite/tremolite. Exsolution of opaques along cleavage in clinopyroxene is quite common (Fig 3c). Biotite, phlogopite, calcite, magnetite occur as the intercummulus phases. Phlogopite is found replacing the pyroxenes. Plagioclases occur in interstitial spaces and are sericitised at places.

Gabbro, a dark grey, medium to coarse grained rock shows inequigranular, ophitic to subophitic textures evident from plagioclases partially or wholly enclosed by pyroxene grains (Fig 3d). Gabbros mainly comprises pyroxenes, amphiboles, plagioclases while biotite, chlorite, epidote, apatite, titanite, sphene as accessory minerals. Opaques of 0.4 to $0.9 \mathrm{~mm}$ size are uniformly distributed throughout the rock. Pyroxenes are transformed to amphiboles and biotite evident from well preserved relict pyroxenes. Chloritisation on the margins of mafic minerals is quite common. Pyroxenes and amphiboles are highly sericitised and epidotised in some of the samples. Plagioclases are lath shaped and fresh or very less altered and zoning is also observed in plagioclases at few places.

Towards the western margin of the Padhar complex are few isolated outcrops of Diorite, a medium to coarse grained grayish rock. Plagioclase, quartz, relict pyroxene, amphiboles are major constituents of the rock. A few plagioclase grains present in the rock are zoned. Accessory minerals present are apatite, sphene, zoisiteand epidote. 


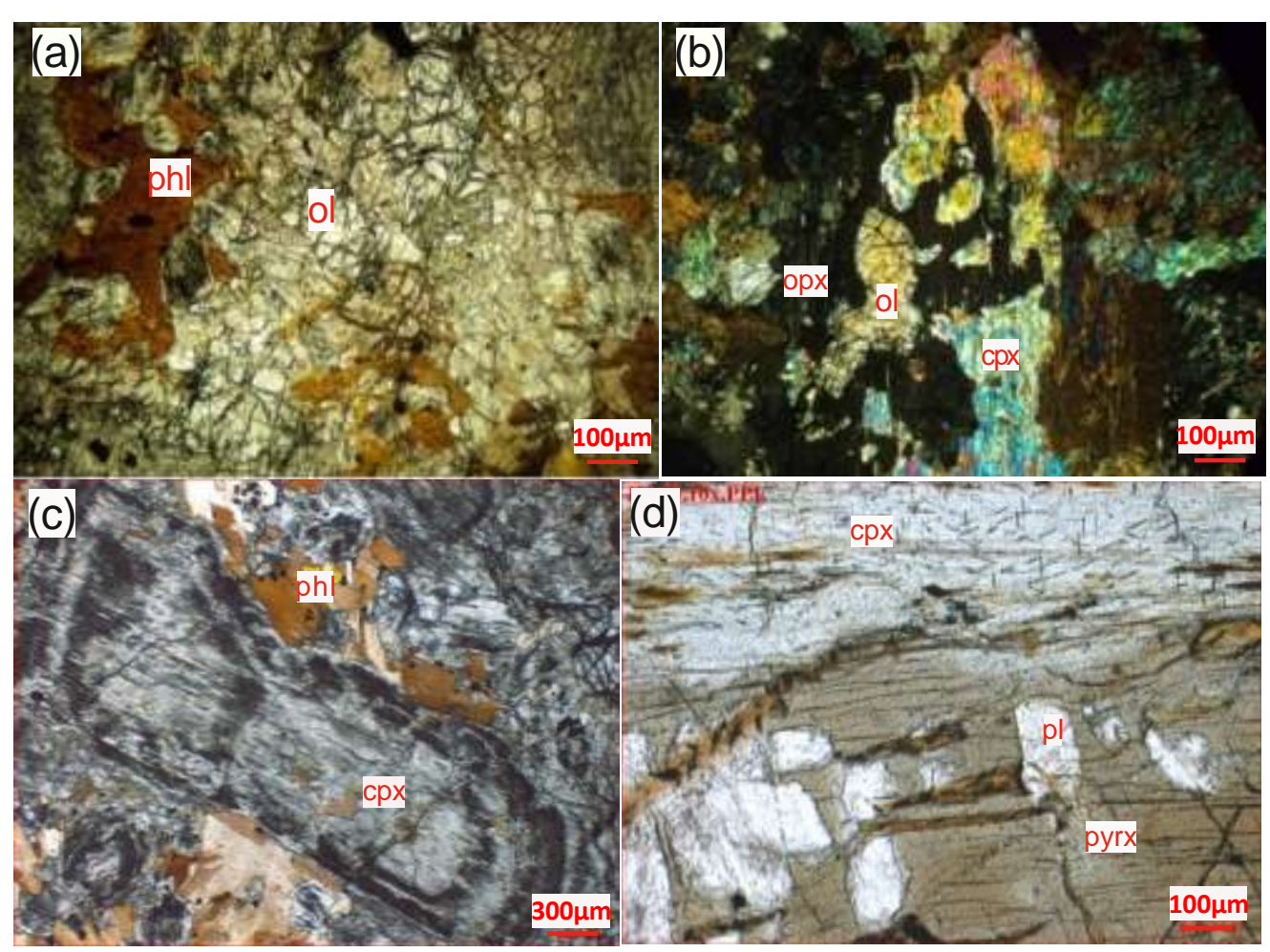

Fig 3. Photomicrographs of the mafic and ultramafic varieties of PMUM rocks (a) olivine grains forming the cumulus phases while phlogopite as intercummulus phase in olivine pyroxenite variety, ppl view; (b) Olivine grain enclosed inside orthopyroxene which in turn surrounded by clinopyroxene grain. Reaction rims around olivine and clinopyroxene. Exsolved opaques in clinopyroxene along cleavage planes; (c) zoning and exsolution of opaques in pyroxene grain and intercummulus phlogopite, ppl view. (d) plagioclase grains fully and partially enclosed in pyroxene grain showing ophitic to subophiotic textures in Gabbro; also observed exsolution of ilmenite along the cleavages in pyroxene grains in the upper part, ppl view;

\section{Whole Rock Geochemistry}

Representative samples of each rock type identified in the study area were selected for whole rock chemical analysis. Major oxide analyses were carried out by X-ray fluorescence Spectrometry (XRF) using Philips MAGIX PRO Model 2440. Trace and REE were determined by Inductively Coupled Plasma Mass Spectroscopy (ICP-MS)using a Perkin Elmer SCIEX ELAN DRC II at CSIR - National Geophysical Research Institute, Hyderabad, India. The procedure, precision and detection limits are the same as given in [17]. The major and trace element data including REE are given in Table 1.

Table 1: Major Oxides (wt \%) and Trace Element concentrations (ppm) of various rock samples from Padhar MUM Complex of Betul Mobile Belt.

\begin{tabular}{|c|c|c|c|c|c|c|c|c|}
\hline & \multicolumn{2}{|c|}{$\begin{array}{l}\text { Olivine } \\
\text { Pyroxenite }(n=3)\end{array}$} & \multicolumn{2}{|c|}{ Pyroxenite $(n=5)$} & \multicolumn{2}{|c|}{ Gabbro $(n=6)$} & \multicolumn{2}{|c|}{ Diorite $(n=4)$} \\
\hline & Av & StDev & $\mathrm{Av}$ & StDev & $\mathrm{Av}$ & StdDev & Av & Std Dev \\
\hline $\mathrm{SiO}_{2}$ & 48.40 & 5.44 & 51.93 & 1.84 & 53.26 & 1.90 & 55.91 & 0.96 \\
\hline $\mathrm{TiO}_{2}$ & 0.80 & 0.83 & 0.42 & 0.13 & 0.70 & 0.24 & 0.59 & 0.09 \\
\hline $\mathrm{Al}_{2} \mathrm{O}_{3}$ & 5.52 & 4.78 & 11.64 & 5.64 & 16.59 & 1.38 & 16.90 & 0.37 \\
\hline $\mathrm{Fe}_{2} \mathrm{O}_{3}$ & 9.89 & 2.57 & 9.14 & 1.96 & 10.13 & 2.27 & 12.04 & 1.03 \\
\hline $\mathrm{MnO}$ & 0.17 & 0.04 & 0.13 & 0.02 & 0.13 & 0.04 & 0.10 & 0.03 \\
\hline $\mathrm{MgO}$ & 21.04 & 10.45 & 9.23 & 4.04 & 6.60 & 1.21 & 4.93 & 0.87 \\
\hline $\mathrm{CaO}$ & 9.25 & 5.43 & 13.35 & 0.91 & 8.30 & 2.64 & 5.00 & 0.48 \\
\hline $\mathrm{Na}_{2} \mathrm{O}$ & 0.54 & 0.60 & 1.10 & 0.77 & 1.21 & 0.28 & 1.73 & 0.18 \\
\hline $\mathrm{K}_{2} \mathrm{O}$ & 0.42 & 0.28 & 0.81 & 0.49 & 0.56 & 0.44 & 1.32 & 0.37 \\
\hline $\mathrm{P}_{2} \mathrm{O}_{5}$ & 0.15 & 0.19 & 0.04 & 0.01 & 0.16 & 0.09 & 0.14 & 0.03 \\
\hline LOI & 1.83 & 0.54 & 2.24 & 0.83 & 1.28 & 0.50 & 1.13 & 0.32 \\
\hline Total & 98.01 & 0.73 & 100.06 & 1.76 & 98.91 & 1.07 & 99.79 & 0.52 \\
\hline Mg\# & 81.87 & 9.49 & 69.43 & 9.48 & 62.06 & 8.32 & 51.12 & 6.45 \\
\hline $\mathrm{FeOt} / \mathrm{MgO}$ & 0.50 & 0.31 & 1.02 & 0.39 & 1.44 & 0.51 & 2.28 & 0.59 \\
\hline Sc & 16.08 & 2.70 & 29.74 & 7.87 & 39.57 & 18.90 & 19.69 & 3.12 \\
\hline
\end{tabular}


Petrography and Geochemistry of Padhar Mafic-Ultramafic Suite, Betul Belt, Central Indian Tectonic

\begin{tabular}{|c|c|c|c|c|c|c|c|c|}
\hline $\mathrm{V}$ & 179.39 & 131.31 & 155.79 & 36.51 & 242.85 & 184.68 & 101.59 & 41.13 \\
\hline $\mathrm{Cr}$ & 2319.36 & 1489.46 & 583.63 & 606.60 & 218.26 & 126.38 & 45.92 & 33.00 \\
\hline $\mathrm{Co}$ & 75.18 & 15.12 & 66.77 & 24.32 & 90.36 & 20.22 & 105.03 & 12.21 \\
\hline $\mathrm{Ni}$ & 520.55 & 379.16 & 259.27 & 260.99 & 75.35 & 34.00 & 20.00 & 11.68 \\
\hline $\mathrm{Cu}$ & 49.19 & 26.23 & 45.73 & 23.11 & 70.02 & 42.28 & 34.74 & 8.02 \\
\hline $\mathrm{Zn}$ & 176.51 & 63.13 & 83.19 & 27.26 & 126.05 & 43.68 & 108.50 & 17.50 \\
\hline $\mathrm{Ga}$ & 13.15 & 12.52 & 11.63 & 2.39 & 21.82 & 4.85 & 21.23 & 0.60 \\
\hline $\mathrm{Rb}$ & 10.40 & 7.28 & 28.51 & 19.15 & 15.79 & 10.24 & 50.70 & 17.81 \\
\hline $\mathrm{Sr}$ & 117.96 & 126.80 & 167.62 & 85.40 & 696.14 & 251.92 & 505.87 & 90.50 \\
\hline $\mathrm{Y}$ & 12.59 & 11.52 & 9.55 & 2.51 & 24.23 & 10.06 & 61.27 & 35.00 \\
\hline $\mathrm{Zr}$ & 27.60 & 16.01 & 20.82 & 6.57 & 37.75 & 5.08 & 122.50 & 40.15 \\
\hline $\mathrm{Nb}$ & 0.20 & 0.23 & 2.77 & 4.65 & 12.69 & 16.05 & 7.47 & 2.24 \\
\hline Cs & 0.88 & 0.71 & 2.88 & 1.76 & 0.72 & 0.44 & 2.20 & 1.73 \\
\hline $\mathrm{Ba}$ & 84.64 & 37.64 & 176.21 & 189.21 & 529.03 & 399.86 & 1114.60 & 610.65 \\
\hline $\mathrm{La}$ & 9.27 & 7.82 & 7.01 & 2.68 & 22.81 & 7.81 & 35.30 & 11.45 \\
\hline $\mathrm{Ce}$ & 22.84 & 21.29 & 14.95 & 6.57 & 46.83 & 16.99 & 64.23 & 22.65 \\
\hline $\operatorname{Pr}$ & 3.72 & 3.64 & 2.08 & 0.83 & 6.35 & 2.44 & 7.24 & 2.28 \\
\hline $\mathrm{Nd}$ & 16.41 & 16.12 & 9.59 & 4.19 & 28.65 & 11.50 & 27.77 & 7.11 \\
\hline $\mathrm{Sm}$ & 3.48 & 3.35 & 2.12 & 0.97 & 5.76 & 2.37 & 5.33 & 1.19 \\
\hline $\mathrm{Eu}$ & 0.85 & 0.78 & 0.76 & 0.41 & 1.73 & 0.56 & 1.65 & 0.17 \\
\hline $\mathrm{Gd}$ & 3.64 & 3.40 & 2.03 & 0.85 & 5.51 & 2.19 & 4.66 & 0.82 \\
\hline $\mathrm{Er}$ & 1.40 & 1.28 & 0.88 & 0.18 & 2.17 & 0.82 & 2.08 & 0.61 \\
\hline $\mathrm{Yb}$ & 1.13 & 0.99 & 0.81 & 0.16 & 1.86 & 0.68 & 2.03 & 0.76 \\
\hline $\mathrm{Lu}$ & 0.17 & 0.15 & 0.11 & 0.03 & 0.25 & 0.09 & 0.32 & 0.12 \\
\hline Hf & 0.82 & 0.61 & 0.62 & 0.14 & 0.94 & 0.07 & 3.15 & 1.40 \\
\hline $\mathrm{Ta}$ & 0.03 & 0.03 & 0.08 & 0.08 & 0.72 & 0.97 & 1.13 & 1.29 \\
\hline $\mathrm{Pb}$ & 8.41 & 2.95 & 4.52 & 1.06 & 3.99 & 2.05 & 22.41 & 13.33 \\
\hline Th & 0.88 & 0.90 & 1.12 & 0.72 & 1.65 & 1.06 & 3.63 & 2.12 \\
\hline $\mathrm{U}$ & 0.29 & 0.26 & 0.25 & 0.14 & 0.23 & 0.11 & 0.87 & 0.48 \\
\hline
\end{tabular}

The $\mathrm{SiO}_{2}$ range for Olivine Pyroxenites is as low as $44.09 \mathrm{wt} \%$ to $54.51 \mathrm{wt} \%$ with an average of 48.40 . $\mathrm{MgO}$ content varies from $12.51 \mathrm{wt} \%$ to as high as $32.69 \mathrm{wt} \%$. The average values for $\mathrm{Fe}_{2} \mathrm{O}_{3}$ and $\mathrm{Al}_{2} \mathrm{O}_{3}$ are low to moderate i.e., 9.89 to $5.52 \mathrm{wt} \%$. Total alkalies $\left(\mathrm{Na}_{2} \mathrm{O}+\mathrm{K}_{2} \mathrm{O}-0.38\right.$ to $\left.1.95 \mathrm{wt} \%\right)$ and $\mathrm{TiO}_{2}$ ranges $(0.30$ to $1.76 \mathrm{wt} \%)$ are also on the lower side. $\mathrm{The}^{\mathrm{SiO}_{2}}$ range for Pyroxenites is relatively higher and varies from 49.77 wt $\%$ to $53.98 \mathrm{wt} \%$ with an average of $51.93 \mathrm{wt} \%$ while the $\mathrm{MgO}$ varies from 6.04 to $15.45 \mathrm{wt} \% . \mathrm{Al}_{2} \mathrm{O}_{3}$ and $\mathrm{Fe}_{2} \mathrm{O}_{3}$ average contents are in moderate range (11.64 and $9.14 \mathrm{wt} \%$, respectively). The $\mathrm{SiO}_{2}$ range for Gabbros shows slightly higher values from pyroxenites with average around $53.26 \mathrm{wt} \%$ and low $\mathrm{Mg \#}$ ranging from 51.20 to $73.6 . \mathrm{Al}_{2} \mathrm{O}_{3}$ values are higher in range (14.33 to 18.59 wt $\%$ ) while $\mathrm{Fe}_{2} \mathrm{O}_{3}$ have moderate to high values (5.82 to $12.33 \mathrm{wt} \%$ ). Total alkalis are towards the higher side with values from 1.11 to $2.76 \mathrm{wt} \%$ while $\mathrm{TiO}_{2}$ values are low with average of $0.24 \mathrm{wt} \%$. The diorites show higher ranges of $\mathrm{SiO}_{2}$ and $\mathrm{Al}_{2} \mathrm{O}_{3}(54.63$ to $56.86 \mathrm{wt} \%)$ and (16.42 to $17.3 \mathrm{wt} \%$ ), respectively. Average $\mathrm{Mg} \#$ for diorites is low i.e. 51.12 showing evolution towards lesser mafic magma batches.

Trace element concentrations for Olivine Pyroxenites include Ni values from 173.69 to $925.34 \mathrm{ppm}$ confirming olivine fractionation and Ba values from 42.00 to as high as $2230.88 \mathrm{ppm}$. Cr values are quite high from 341.58 to $2480.9 \mathrm{ppm}$ with one sample (PJ-109) having exceptional high value of $3721.47 \mathrm{ppm}$ indicating its most primary komatitic composition. Pyroxenites have moderate values for $\mathrm{Ni}$ (91.69 to 711.9ppm) and $\mathrm{Cr}$ (69.56 to $1261.8 \mathrm{ppm}$ ). The average $\mathrm{Ni}$ and $\mathrm{Cr}$ concentrations in Gabbros are low i.e., $75.35 \mathrm{ppm}$ and 218.26 ppm, respectively.

\section{Discussion}

The TAS classification diagram proposed by Le Maitre, 1989 of $\mathrm{Na}_{2} \mathrm{O}+\mathrm{K}_{2} \mathrm{O}$ versus $\mathrm{SiO}_{2}$ and $\mathrm{Nb} / \mathrm{Y}$ versus $\mathrm{SiO}_{2}$ (Fig $4 \mathrm{a} \& \mathrm{~b},[18]$ ) indicates that most of the samples range from basaltic to basaltic andesites, falling in sub-alkaline fields except one sample falling in picro basalt field. The AFM Diagram (Fig 4c: after Irvine and Baragar, 1971, [19]) depicts magma type as tholeiitic but trending towards calc-alkaline nature. A $\mathrm{SiO}_{2}-\mathrm{K}_{2} \mathrm{O}$ plot (Fig 4d; after Peccerillo and Taylor, 1976, [20]) indicates that Olivine Pyroxenites, Pyroxenites and Gabbros belong to low $\mathrm{K}$ tholeiites whereas few Gabbros and Diorites fall in medium K calc-alkaline series.

Major oxides have been plotted against $\mathrm{Mg \#}$ to understand the process of fractional crystallisation or magmatic evolution (Fig 5a-f). The Pyroxenites and Gabbros show increasing trends of $\mathrm{SiO}_{2}, \mathrm{Al}_{2} \mathrm{O}_{3}, \mathrm{TiO}_{2}$ and

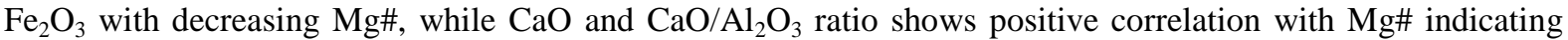
fractionation of clinopyroxenes. Olivine fractionation is indicated by constant $\mathrm{CaO} / \mathrm{Al}_{2} \mathrm{O}_{3}$ ratios [21]. Increasing ratios of $\mathrm{CaO} / \mathrm{Al}_{2} \mathrm{O}_{3}$ indicates fractional crystallization of plagioclases. 
(a)
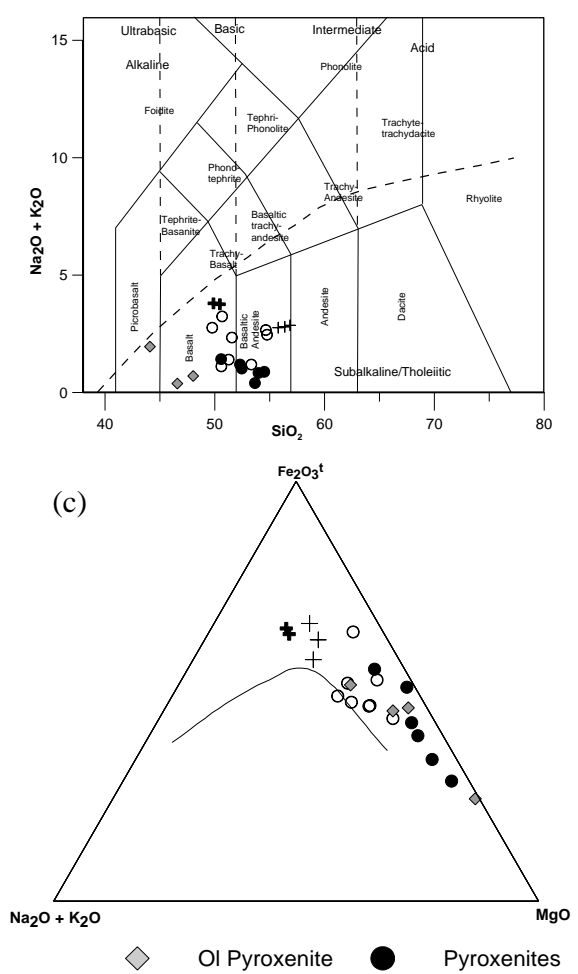

(b)

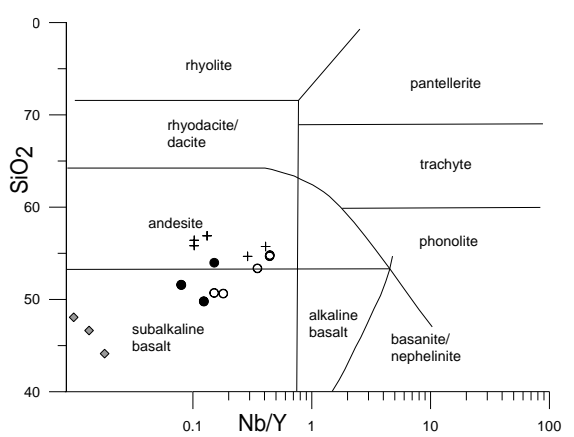

(d)

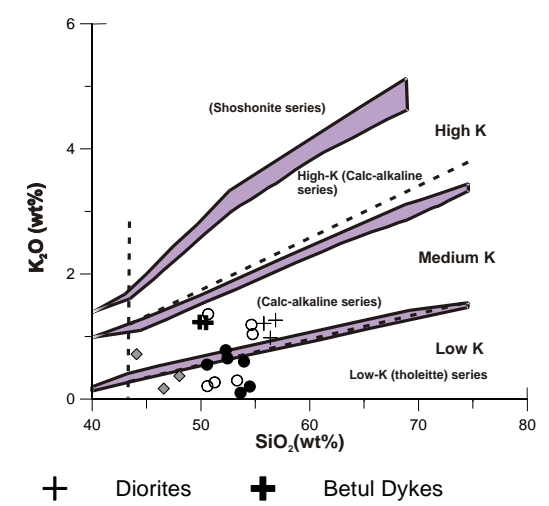

Fig 4. Classification Plots of PMUM rocks, Betul. (a) Total Alkali vs Silica diagram (after Le Maitre,1989);

(b) $\mathrm{Nb} / \mathrm{Y}$ vs SiO2 diagram (after Le Maitre,1989); (c) AFM ternary diagram (after Irvine and Baragar, 1971); (d) SiO2 vs K2O binary diagram (after Pecerillo \& Taylor, 1976)

The trace element concentrations show positive correlation of $\mathrm{Ba}, \mathrm{Cr} \& \mathrm{Ni}$ while negative correlation of $\mathrm{Y}$ against $\mathrm{Mg \#}$ is an evidence for early partioning of $\mathrm{Ni}$ in Olivine and $\mathrm{Cr}$ in Chromite (Fig 6a \& b). These trends are indicative of the magma differentiation similar to arc/backarc environment such as those of Barren arc volcanic [22-24]. The $\mathrm{Cr}$ and Co versus Ni gives evidence of element fractionation with evolution (Fig 6c \& d).
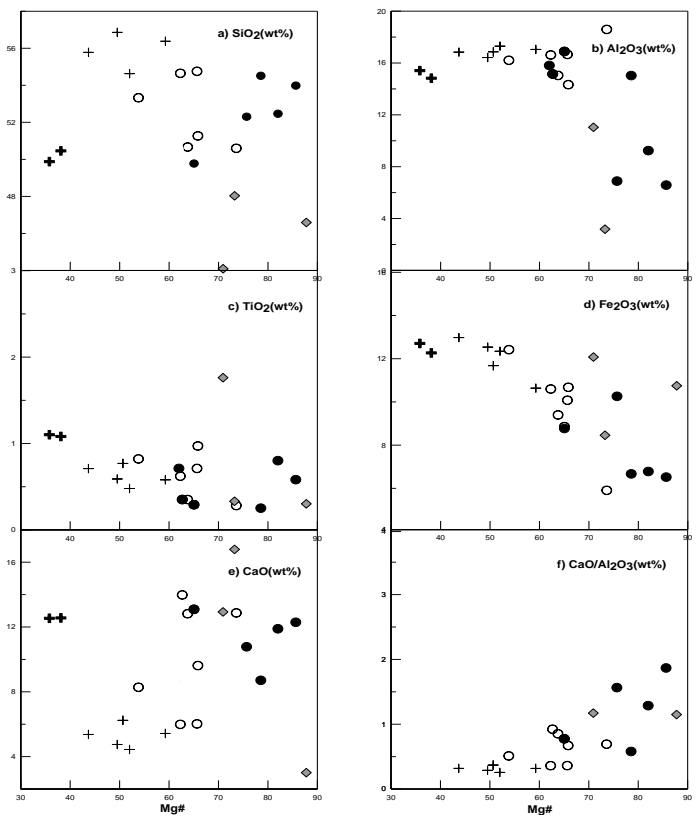

Fig 5. Harker variation diagrams of major oxide compositions (a) $\mathrm{Mg \#} \mathrm{vs.} \mathrm{SiO}_{2} \mathrm{wt} \%$ (b) $\mathrm{Mg \#}$ vs. $\mathrm{Al}_{2} \mathrm{O}_{3}$ wt $\%$ (c) $\mathrm{Mg \#}$ vs. $\mathrm{TiO}_{2}$ wt $\%$ (d) $\mathrm{Mg \#}$ vs. $\mathrm{Fe}_{2} \mathrm{O}_{3}$ wt $\%$ (e) $\mathrm{Mg \#}$ vs. $\mathrm{CaO}$ wt\% (f) $\mathrm{Mg \#}$ vs. $\mathrm{Cao} / \mathrm{Al}_{2} \mathrm{O}_{3}$ ratio.
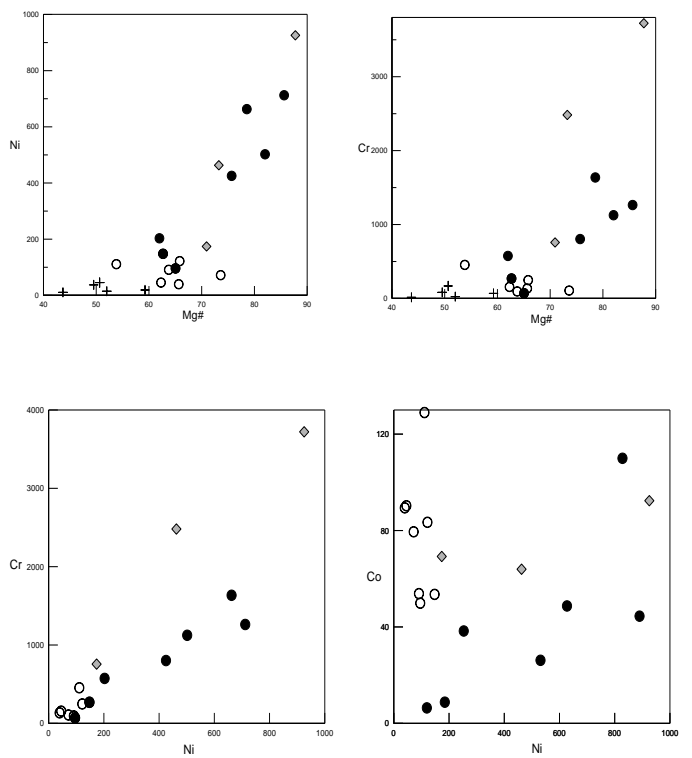

Fig 6. Harker diagram of trace element compositions (a) Mg\# vs. Ni (in ppm) (b) Mg\# vs. Cr (in ppm). (c) $\mathrm{Cr}$ vs. Ni (in ppm) (d) Co vs. Ni (in ppm). Symbols as in Fig 4. 
Among the incompatible elements the significant negative $\mathrm{Nb}$ anomaly with respect to $\mathrm{Th}$ and $\mathrm{Ce}$ points towards Volcanic Arc Basalt (VAB) settings. Tholelitic VAB shows absolute depletion of $\mathrm{Nb}, \mathrm{Zr}$, Ti and $\mathrm{Y}$ relative to $\mathrm{N}-\mathrm{MORB}$, with gradual enrichment of $\mathrm{Nb}$ and $\mathrm{Zr}$ in calc-alkaline varieties while $\mathrm{Ti}$ and $\mathrm{Y}$ maintaining their low abundances [25].

Chondrite normalised REE plots of the Padhar Mafic-Ultramfic rocks (Fig 7a) show mild enrichment of LREE in ultramafic varieties $\left((\mathrm{La} / \mathrm{Sm})_{\mathrm{N}}\right.$ ratio varies from 0.87 to 3.07) which becomes stronger towards Gabbros and Diorites $\left((\mathrm{La} / \mathrm{Sm})_{\mathrm{N}}\right.$ ratio varies from 2.16 to 4.88$)$ indicating fractionation. HREE shows low to mild enrichment with average $(\mathrm{La} / \mathrm{Yb})_{\mathrm{N}}$ ratios of ultramafic varieties as 5.19 and for Gabbros and Diorites as 6.19 and 12.65, respectively. The trace element spidergram (Fig 7b) normalised after values in Sun and Mc Donough, 1989, [26] shows slight LREE enrichment with flat HREE pattern and slight positive Eu anomalies. Significant negative $\mathrm{Nb}$ anomalies relative to enriched $\mathrm{Th}$ and $\mathrm{Ce}$ values indicates fractionation of $\mathrm{Nb}$ from $\mathrm{Th}$ and Ce during dehydration and partial melting of subducted crust [27]. The Th and $\mathrm{Ce}$ are transferred from subducting plate to sub-arc melting column while $\mathrm{Nb}$ is retained in mineral phases like amphibole, titanite and rutile in the subducting plate and overlying mantle lithosphere.
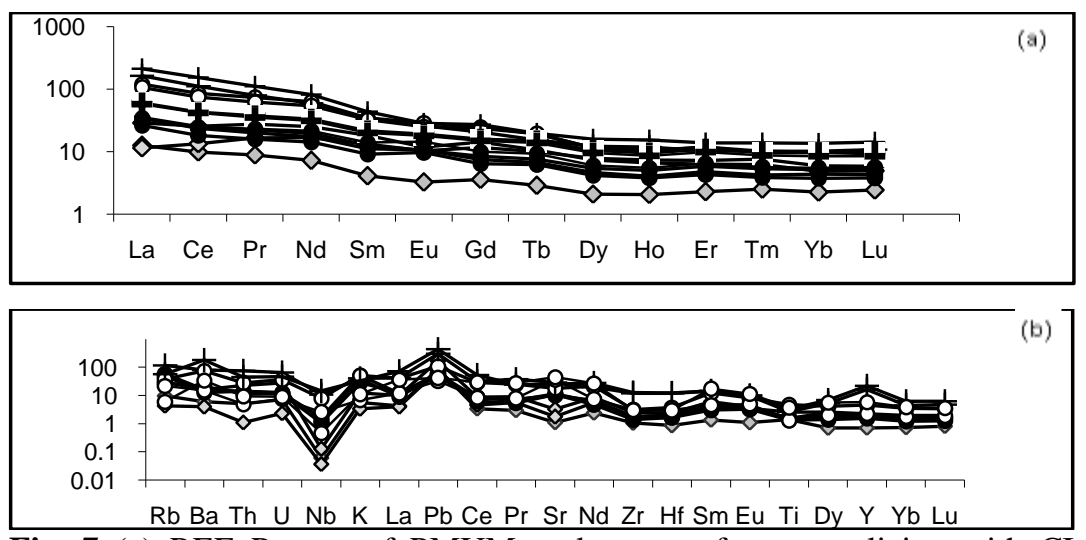

Fig. 7 (a) REE Pattern of PMUM rock types after normalizing with CI chondrite (Sun \& McDonough, 89); (b) Trace element spidergram after normalizing with Primitive mantle values (Sun \& McDonough 89). Symbols as in Fig 4.

The enrichment of Large ion lithophile (LILE) $(\mathrm{Pb}, \mathrm{K}, \mathrm{Rb}, \mathrm{Ba}, \mathrm{Sr}$ ) elements and depletion in High field strength ions (e.g. Zr, Nb, Hf) relative to N-MORB (N-type) is attributed to LILE mobility of fluids derived from dehydrating subduction sediments which enriches the mantle beneath arc without influencing the high field strength ions [28]. So, the trace element pattern indicates the source of magma to be subcontinental lithospheric mantle with metasomatism by fluids from subducting sediments.

The negative $\mathrm{Nb}$ anomalies points towards crustal contamination but negative $\mathrm{Zr}-\mathrm{Hf}$ troughs do not support this as crust is enriched in these elements. The low $\mathrm{Th} / \mathrm{Yb}$ values in olivine pyroxenites and pyroxenites along with negative $\mathrm{Zr}-\mathrm{Hf}$ troughs suggest against crustal contamination. The low $\mathrm{Nb} / \mathrm{La}(0.009-0.6)$ and $\mathrm{Nb} / \mathrm{Ce}(0.003-0.4)$ values for all the rock types also points against any crustal contamination. Only the evolved phases like Diorites shows signatures of crustal contamination.

For petrogenetic evolution, discrimination diagrams have been plotted. In a ternary diagram proposed by Mullen,1983, (Fig 8a), [29] most of the Olivine Pyroxenites and Pyroxenites occupy Boninitic field while Gabbros and Diorites occupy Island Arc Tholeiite (IAT) field with minor amount of dioritic samples straddling around Calc Alkaline Basalt (CAB) field indicating multiple batches of magma emplacement in volcanic arc environment with boninitic-tholeiitic to calc-alkaline affinity of the rocks. The trace element ratio diagrams i.e., the Ti vs. V after Shervais, 1982(Fig 8b; [30]) indicates volcanic arc setting of magma series with little overlap in Mid Oceanic Ridge Basalts (MORB) field. The Th-Ta-Hf ternary diagram after Wood et al, 1979 (Fig 8c; [31]) distinguish VAB from other types of Magma especially MORB, thus indicates volcanic arc settings with selective enrichment of Th and depletion of $\mathrm{Ti}, \mathrm{Y}$ and $\mathrm{Zr}$ (or $\mathrm{Hf}$ ) relative to N-MORB. The Sc/Ni versus $\mathrm{La} / \mathrm{Yb}$ plot after Bailey, 1981 (Fig 8d; [32]) shows affinity towards continental arc settings. The protoliths of these rocks are observed to be derived from Spinel-peridotite mantle composition as inferred from the $\mathrm{Lu} / \mathrm{Hf}$ versus La/Sm ratio plot proposed by Regelous et.al., 2003 (Fig 9; [33]). 
(a)

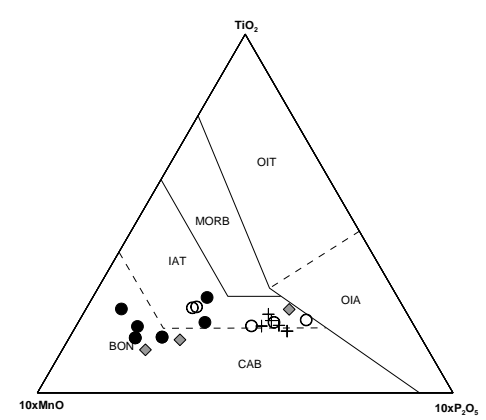

(c)

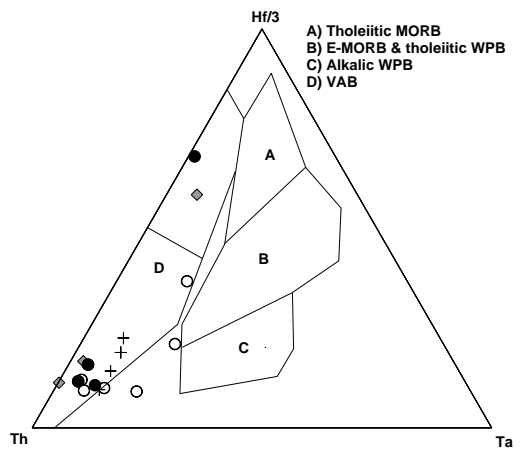

(b)

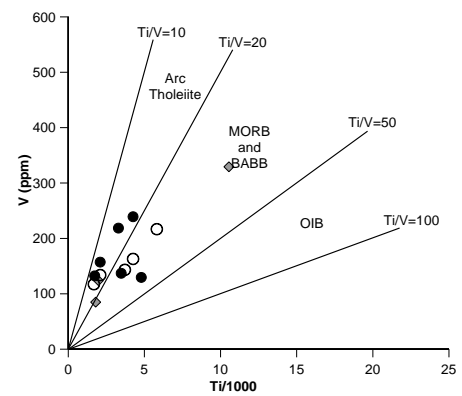

(d)

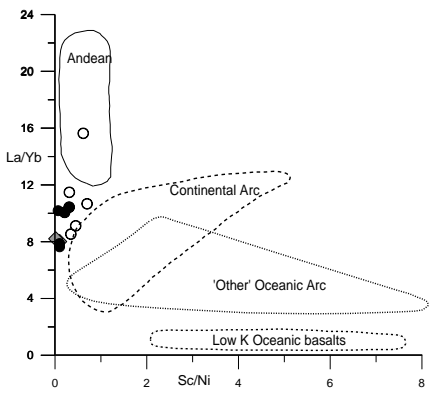

Fig. 8 Tectonic Discrimination diagrams of Padhar MUM Rocks, Betul. (a) TiO2-MnO-P2O5 ternary diagram (Mullen 1983); (b) V(ppm) vs. Ti(ppm) discrimination diagram (after Shervais 1982). (c) $\mathrm{Ti} \mathrm{Vs} \mathrm{Zr}$ (ppm)tectonic diagram (after Pearce et al,1981); (d) Ti-y-Zr (ppm) ternary diagram (Pearce and Cann 1973); (e) Th-Ta-Hf (ppm) ternary diagram(wood et al, 1979). Abbreviations: OIA: Ocean Island alkali basalts; CAB: calc-Alkaline Basalts; IAT: Island Arc Tholeiites; MORB: Mid Oceanic Ridge Basalts; BON: Boninitic; WPB: Within Plate Basalts. (f) $\mathrm{La} / \mathrm{Yb}$ vs $\mathrm{Sc} / \mathrm{Ni}$ plot showing continental arc affinity for the mafic-ultramafic rocks of Padhar complex (after Bailey, 1981).Symbols as in Fig 4.

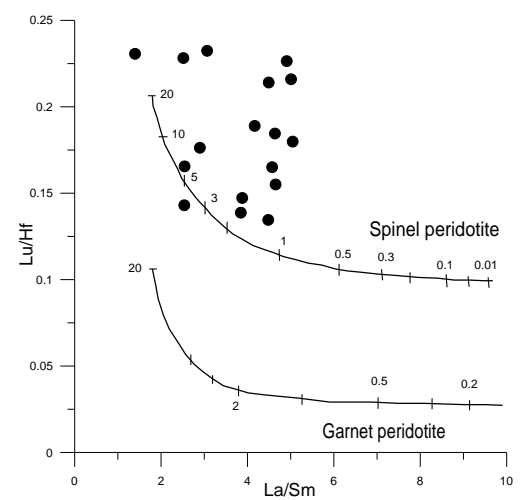

Fig. 9. Lu/Hf vs La/Sm ratios of PMUM rocks for partial melting (after Regelous et al., 2003)

\section{Conclusion}

The Padhar Mafic-Ultramafic suite of rocks represents Arc Tholeiitic magmas of basaltic to basalticAndesitic compositions derived from spinel peridotite. The presence of cumulates of olivine, pyroxene and intercummulus phlogopite indicates primitive source of magma. The higher concentrations of $\mathrm{Pb}, \mathrm{K}, \mathrm{Rb}$ and $\mathrm{Sr}$ suggest metasomatism by fluids derived from sediments of subducting plate. The evolutionary trends towards mafic varieties like gabbros and diorites with slight increase in LILE enrichment and $\mathrm{Zr}-\mathrm{Hf}$ trough indicates multiple phases of intrusion of mafic magma intrusions in separate batches. So the Padhar Mafic-Ultramafic suite of rocks represent the mafic magmatism in subduction environment with metasomatised magmas emplaced in continental arc settings.

\section{Acknowledgements}

The facilities provided by CAS in Geology, Panjab University, Chandigarh for field work and Petrological studies are highly acknowledged. Satinder Dhillon, also thank scientists at NGRI, Hyderabad for major and trace element analyses. 


\section{References}

[1] S.K. Acharya, and A. Roy, Tectonothermal history of the Central Indian Tectonic Zone and reactivation of major fault/shear zones. Journal of Geological Society of India, 55, 2000, 239-256.

[2] B.P. Radhakrishna, Suspect tectono-stratigraphic terrane elements in the Indian subcontinent. Journal of Geological Society of India, 34, 1989, 1-24.

[3] D.B. Yedekar, S.C. Jain, K.K.K. Nair, K.K. Dutta, The Central Indian collision suture. Precambrian of Central India, Geological Survey of India, Special Publication, 28, 1990, 1-37.

[4] A. Roy, and M. Hanuma Prasad, Tectonothermal events in Central Indian Tectonic Zone (CITZ) and its implications in Rodinian crustal assembly. Journal of Asian Earth Sciences, 2003, 22, 115-129.

[5] A. Roy, and K. Chakraborti, Precambrian mafic-ultramafic magmatism in central Indian suture zone, Journal of Geological Society of India, 72(1), 2008, 123-140.

[6] A. Dombrowski, F. Henjes-Kunst, A. Höhndorf, A. Kröner, M. Okrusch, and P. Richter, Orthogneisses in the Spessart Crystalline Complex, north-west Bavaria: Silurian granitoid magmatism at an active continental margin.Geolgische Rundschau, 84, 1995, 399411.

[7] E.C. Ferré, R. Caby, J.J. Peucat, R. Capdevila, and P. Monié, Pan-African, post-collisional, ferro-potassic granite and quartzmonzonite plutons of eastern Nigeria. Lithos, 45, 1998, 255-279.

[8] O. Eklund, D. Konopelko, H. Rutanen, S. Fröjdö, and A.D. Shebanov, 1.8 Ga Svecofennian post-collisional shoshonitic magmatism in the Fenno-scandian shield. Lithos, 45, 1998, 87-108.

[9] J.B. Whalen, G.A. Jenner, E. Hegner, C. Gariepy, and F.J. Longstafee, Geochemical and isotopic (Nd, O and Pb) constraints on granite sources in the Humber and Dunnage zones, Gaspésie, Quebec and New Brunswick : Implications for tectonics and crustal structure. Canadian Journal of Earth Sciences, 31, 1994, 323-340.

[10] J.X. Zhao, and M.T. McCulloh, Geochemical and Nd isotopic systematics of granites from the Arunta Inlier, central Australia: implications for Proterozoic crustal evolution. Precambrian Research, 71, 1995, 265-299.

[11] A. Roy, S.A. Chore, L.L. Viswakarma, and K. Chakraborty, Geology and petrochemistry of Padhar mafic-ultramafic complex from Betul belt: A study of arctype magmatism in Central Indian Tectonic Zone. Geological Survey of India, Special Publication, 84, 2004, 297-318.

[12] S.K. Shrivastava, and S. K. Chellani, Special thematic mapping of Archaean Proterzoic rocks of Bordehi and Khari area. Betul district, MP. Geological Survey of India, Records, 129(6), 1995, 91-95.

[13] R.K. Chaturvedi, Review of geology, tectonic features and tectono-stratigraphy of Betul Belt. Geological Survey of India, Special Publication, 64, 2001, 229-315.

[14] S.P. Mahakud, P.K. Raut, C. Hansda, P.F. Ramteke, U. Chakraborty, M.N. Praveen, and D.S. Sisodiya, Sulphide mineralization in the central part of Betul belt around Ghisi-Muariya-Koparpani area, Betul district, Madhya Pradesh. Geological Survey of India, Special Publication, 64, 2001, 377-385.

[15] A. Roy, and M.H. Prasad, Tectonomagmatic history of Tan Shear Zone and its environs: a preliminary study. Geological Survey of India, Special Publication, 64, 2001, 273-287.

[16] M.N. Praveen, B. Ghosh, H.S. Srivastava, M.L. Dora, and L.D. Gaikwad, Sulphide Mineralisation in Betul Belt: Classification and General Characteristics. Journal of Geological Society of India, 69, 2007, 85-91

[17] V. Balaram, and T.G. Rao, Rapid determination of REEs and other trace elements in geological samples by microwave acid digestion and ICP-MS, Atomic spectroscopy 24 (6), 2003, 206-212.

[18] R.W. Le Maitre(ED), A classification of igneous rocks and glossary of terms (with P. Bateman, A. Dudek, J. Keller, J. Lameyere, M.J. LaBas, P.A. Sabine, R. Schmid, H. Srensen, A. Streckei Sen, A.R. Wooley and B. Zanethim) BlackWell, Oxford, $193,1989$.

[19] T.N. Irvine, and W.R. Baragar, A guide to chemical classification of common volcanic rocks. Canadian Journal of Earth Science, $8,1979,523-548$.

[20] R. Peccerillo, and S.R. Taylor, Geochemistry of Eocene calc-alkalic volcanic rocks from the Kastamanu area, northern Turkey. Contributions to Mineralogy and Petrology, 58, 1976, 63-81.

[21] M.A. Dungan and J.M. Rnodes, Residual glasses and melt inclusionsin basalts from DSDP Legs 45 and 46 : evidence for magma mixing. Contributions to Mineralogy and Petrology, 67, 1978, 417-431.

[22] J.F. Luhr, and D. Haldar, Barren Island Volcano (NE Indian Ocean): island-arc high alumina basalts produced by troctolite contamination. Journal of Volcanology and Geothermal Research, 149, 2006, 177-212.

[23] J.A. Pearce, P.E. Baker, P.K. Harvey, I.W. Luff, Geochemical evidence for subduction fluxes, mantle melting and fractional crystallization beneath the South Sandwich Island arc., Journal of Petrology, 36, 1995, 1073-1109.

[24] R. Shinjo, S.L. Chung, Y. Kato, and M. Kimura, Geochemical and Sr-Nd isotopiccharacteristics of volcanic rocks from the Okinwa Trough and Ryukyu Arc: implications for the evolution of a young, intracontinental back arc basin. Journal of Geophysical Research, 104 (B5), 1999, 10591-10608.

[25] J.A. Pearce, A user's guide to basalt discrimination diagrams, in Wyman, D.A., ed., Trace Element geochemistry of volcanic rocks: Applications for massive sulphide exploration: Geological Association of Canada, Short course notes, 12, 1996, $79-113$.

[26] S.S. Sun, and W.F. McDonough, Chemical and isotopic systematics of Oceanic basalts: implications for mantle compositions and processes in: Sanaders A.D., Norry, M.J., magmatism in the ocean basins, Geological society of London, special Publication, 42, $1989,313-345$

[27] J.A. Pearce, D.W. Peate, Tectonic implications of the composition of volcanic arc magmas. Annual Review of Earth and Planetary Science, 23, 1995. 251-285.

[28] A.D. Saunders, J. Tarney, and S.D. Weaver, Transverse geochemical variations across the Antarctic Peninsula: implications for the genesis of calc-alkaiine magmas. Earth and Planetary Science Letters, 46, 1980, 344--360.

[29] E.D. Mullen, MnO/TiO2/P2O5: A minor element discriminant for basaltic rocks of oceanic environments and its implications for petrogenesis. Earth and Planetary Science Letters, 62, 1983, 53-62.

[30] J.W. Shervais, Ti-V plots and the petrogenesis of modern and ophiolitic lavas. Earth and Planetary Science Letters, 87, 1982, 341370 .

[31] D.A. Wood, J. Tarney, J. Varet, A.D. Saunders, H. Bougault, J.L. Joron, M. Treuil, and J.R. Cann, Geochemistry of basalts drilled from north Atlantic by IPOD leg 49 implications for mantle heterogeneity. Earth and Planetary Science Letters, 42, $1979,77-97$.

[32] J.C. Bailey, Geochemical criteria for a refined tectonic discrimination of orogenic andesites. Chemical Geology, 32, $1981,139-154$.

[33] M. Regelous, A.W. Hofmann, and W. Aboucham, Geochemistry of lavas from the emperor seamounts and the geochemical evolution of Hawaiian magmatism from 85 to 42 Ma. Journal of Petrology, 44, 2003, 113-140. 